\title{
Frequency of Th9 Cells in Different Stages of Rheumatoid Arthritis
}

\section{Hadi Bazzazi (PhD)}

Department of Molecular Medicine, School of Advanced Technologies in Medicine, Golestan University of Medical Sciences, Gorgan, Iran

Yaghoub Yazdani (PhD)

Infectious Diseases Research Center, Golestan University of Medical

Sciences, Gorgan, Iran

Nasser Behnampour (PhD)

Public Health Department, Faculty of Health, Golestan University of Medical

Sciences, Gorgan, Iran

Hadi Hossein-Nataj (PhD)

Department of Immunology, Mazandaran University of Medical

Sciences, Sari, Iran

Ali Memarian (PhD)

Stem Cell Research Center, Golestan University of Medical Sciences,

Gorgan, Iran

Mehrdad Aghaei (MD, PhD)

Division of Rheumatology,

Department of Internal

Medicine. Head, Joint, Bone,

Connective tissue, Rheumatology

Research Center (JBCRC) Deputy,

Research \& Development, Sayyad

Shirazi Teaching Hospital, Golestan

University of Medical Sciences,

Gorgan, Iran

Corresponding author: Mehrdad

Aghaei

Tel: +989111754556

Email: draghaei-m@goums.ac.ir

Address: Sayyad Shirazi Teaching

Hospital, Golestan University of

Medical Sciences, Gorgan, Iran

Received: 14 Nov 2018

Revised: 02 Jan 2019

Accepted: 14 Jan 2018

\section{(c) (7) (5)}

This work is licensed under a Creative Commons Attribution 4.0 License.

\begin{abstract}
Background and Objectives: $T$ helper (Th) lymphocytes play a key role in the pathogenesis of autoimmune diseases. As a new subset of lymphocytes, Th9 is thought to be involved in a wide range of disorders including rheumatoid arthritis (RA). In this study, we evaluated frequency of Th9 and Th2 cells and its correlation with disease activity in patients with different stages of RA.

Methods: The frequency of circulating interleukin 9- and/or interleukin 4producing CD3+CD8-T cells was determined among 41 patients with established RA, 14 patients with very early RA (VERA) and 23 healthy controls by flow cytometry analysis. Then, correlation of cell frequencies with disease activity score 20 (DAS-28) was assessed. Serum levels of interleukin 6 and anti-citrullinated peptide antibodies were measured by enzymelinked immunosorbent assay.

Results: Frequency of Th9 cells was significantly higher in RA patients compared to healthy controls $(\mathrm{P}=0.009)$. Moreover, mean percentage of circulating Th9 cells in patients with inactive VERA was significantly higher than that in those with active disease $(\mathrm{P}=0.046)$. In addition, mean percentage of Th9 cells had a negative correlation with the DAS-20 (r=$0.568, \mathrm{P}<0.05)$. There was no significant correlation between the mean serum level of interleukin 6 and percentage of Th2 and Th9 cells $(\mathrm{P}>0.05)$.

Conclusion: 0ur results suggest that Th9 cells may have a potential role in RA initiation. Thus, targeting Th9 cells could be a promising strategy for advanced RA therapies.

Keywords: Rheumatoid arthritis, Th2 cells, Th9 cells.
\end{abstract}

This paper should be cited as: Bazzazi $H$, Yazdani Y, Behnampour N, Hossein-Nataj H, Memarian A, Aghaei M[Frequency of Th9 Cells in Different Stages of Rheumatoid Arthritis]. mljgoums. 2019; 13(6):29-35 


\section{INTRODUCTION}

Rheumatoid arthritis (RA) is a systemic autoimmune disease that can cause progressive inflammation in peripheral joints (1). It affects $0.5-1 \%$ of the world's population (2). Although diverse genetic, immunological and environmental factors are associated with development of RA, auto-reactive $T$ lymphocytes play a particularly important role in the disease initiation and manifestation (3). The role of $\mathrm{CD}^{+} \mathrm{T}$ cells in the pathogenesis of RA is well-established (4). According to the cytokine milieu, $\mathrm{CD}^{+} \mathrm{T}$ lymphocytes may differentiate into diverse populations each of which may play a distinct role in immune responses (5). Th1 cells predominantly mediate immunity against intracellular pathogens, whereas Th2 cells are mainly involved in defense against extracellular parasites, asthma and allergens (6). Th17 cells take part in immunity against some extracellular bacterial and fungal pathogens (7). Although Th1 and Th17 cells are considered as main $\mathrm{T}$ cell subsets in RA pathogenesis (8), other $\mathrm{T}$ cell subsets such as Th2 and Th9 have also been proposed to be involved in autoimmunity (9). As newly described effector subsets, Th9 cells dominantly produce interleukin-9 (IL-9). These cells are involved in various disorders ranging from autoimmune diseases to allergic diseases $(10,11)$. As the signature cytokine in Th9 cells, IL-9 is increased in serum and synovial fluid of RA patients (12). It should be noted that IL-9 is an ambiguous and pleiotropic cytokine that can induce survival of different $\mathrm{T}$ cell subtypes via its receptor (13). Some studies have suggested the plasticity between Th 2 and Th9 cells, and the fact that these subsets can change to each other depending on the microenvironments they are exposed to (14). The anti-citrullinated protein antibody (ACPA) is found in majority of RA patients and is valuable for diagnosis of the disease. Based on the presence of ACPA in serum, RA could be subdivided into two distinct subsets; ACPA-positive and ACPAnegative RA (1). ACPA-positive RA patients are more likely to have an aggressive disease phenotype with higher rates of erosive damage (15). The roles of inflammatory cytokines, Th2 and Th9 in different stages of RA are not thoroughly understood. Hence, we evaluated serum level of IL- 6 and frequency of Th2 and Th9 cells in peripheral blood of healthy individuals and RA patients with different disease stages and activities.

\section{MATERIALS AND METHODS}

The study included 55 RA patients diagnosed by a rheumatologist based on the American College of Rheumatology/European League Against Rheumatism criteria (2010) (16). Peripheral blood samples were obtained from patients at Sayyad Shirazi Teaching Hospital, Gorgan, Iran. Based on the disease stages, the patients were divided into two subgroups: very early RA (VERA) and established RA. Disease duration in VERA patients was less than three months after the first signs of RA (17). VERA patients were not receiving any treatment. Disease duration of established RA patients was at least three months after the onset of early signs of RA. Established RA patients were receiving prednisolone and disease-modifying antirheumatic drugs (DMARDs) such as methotrexate, hydroxychloroquine and sulfasalazine. The patients were classified as having active or inactive disease according to the disease activity score of 28 joints (DAS28) (18). None of the patients had chronic infection or inflammatory disease other than RA. Twenty-three age- and gender-matched healthy controls were also randomly selected from the same hospital. This study was approved by the ethics committee of the Golestan University of Medical Sciences (Code of Ethics: 31078693122410), and a written informed consent was obtained from all participants after fully explaining the study objectives and procedures.

Initially, $500 \mu \mathrm{L}$ of diluted sodium-heparinized whole peripheral blood of each subject were cultured in $2 \mathrm{ml}$ of RPMI 1640 supplemented with $10 \% \mathrm{FBS}, 100 \mathrm{U} / \mathrm{ml}$ penicillin and 100 $\mu \mathrm{g} / \mathrm{ml}$ streptomycin (GIBCO, USA). Then, it was stimulated with phorbol myristate acetate (PMA, $40.5 \mu \mathrm{M}$, eBioscience, USA) plus ionomycin $(670 \mu \mathrm{M}$, eBioscience, USA) for 5 hours in the presence of brefeldin A $(5.3 \mathrm{mM})$ and monensin ( $1 \mathrm{mM}$, eBioscience, USA) at $37{ }^{\circ} \mathrm{C}$ and $5 \% \mathrm{CO}_{2}$. Later, $100 \mu \mathrm{l}$ of activated cells were incubated with peridininchlorophyll protein complex-cyanine5.5labeled anti-human CD3 (Biolegend, USA) and fluorescein isothiocyanate-labeled antihuman CD8a (Biolegend, USA). Because CD4-positive cells would turn into CD4- 
negative cells after the stimulation with PMA, we used anti-human CD8 for surface staining and analyzed $\mathrm{CD}^{+} \mathrm{CD}^{-}$cells instead of $\mathrm{CD}^{+} \mathrm{CD}^{+}$cells (19). After elimination of erythrocytes using lysis buffer, cells were fixed and permeabilized with $1 \mathrm{X}$ intracellular fixation and permeabilization buffer (eBioscience, USA). For intracellular cytokine staining, the cells were mixed with phycoerythrin-labeled anti-human IL-9 (Biolegend, USA) and allophycocyaninlabeled anti-human IL-4 (Biolegend, USA). Isotype controls (Biolegend, USA) were used for confirmation of antibody specificity. The labeled, fixed cells were analyzed the same day for cytoplasmic cytokines with a 4-color BD Accuri C6 flow cytometer (BectonDickinson Bioscience, USA) followed by analysis with FlowJo 7.6 (Tree Star, USA). The profile of the $\mathrm{CD}^{+} \mathrm{CD} 8 \mathrm{~T}$ cells was defined by their ability to exclusively express IL-9 (Th9 cells) and IL-4 (Th2 cells).

Determination of the serum ACPA (IgG) antibodies was performed using a commercial enzyme-linked immunosorbent assay kit (Euroimmun, Germany). The ACPA of more than $5 \mathrm{U} / \mathrm{ml}$ was considered positive. Serum level of IL-6 was determined using commercially available enzyme-linked immunosorbent assay kits (Biolegend, USA). Presence of rheumatoid factor (RF) was assessed in all sera using the standard AVITEX slide latex agglutination test (Omega Diagnostics, UK).

All statistical analyses were carried out using SPSS version 22 and GraphPad Prism 5.04. The Kruskal-Wallis test was used to compare nonparametric means of multiple samples. Pvalues less than 0.05 were considered statistically significant. Positive r-values represent a positive correlation while negative r-values represent a negative correlation.

\section{RESULTS}

Overall, 55 RA patients with a mean age of $48.34 \pm 2.62$ years and 23 healthy controls with mean age of $41.78 \pm 1.30$ years were included in the study. Fourteen patients had VERA ( $\leq 3$ months in duration). Twenty-six patients had active disease with a DAS-28 of $>$ 3.2 , while 29 patients had quiescent disease (DAS-28 < 3.2). Demographic and clinical characteristics of patients and healthy controls are presented in table 1 .

Table 1- Clinical characteristics of RA patients and healthv controls

\begin{tabular}{|c|c|c|c|c|}
\hline Characteristics & $\begin{array}{c}\text { Very early RA } \\
(n=14)\end{array}$ & $\begin{array}{c}\text { Established RA } \\
(n=41)\end{array}$ & $\begin{array}{l}\text { Healthy controls } \\
(\mathbf{n}=23)\end{array}$ & P-value \\
\hline Age & $50.64 \pm 4.41$ years & $46.04 \pm 1.79$ years & $41.78 \pm 1.30$ years & 0.466 \\
\hline Sex (male/female) & $4 / 10$ & $1 / 40$ & $3 / 20$ & 0.093 \\
\hline BMI & $18.92 \pm 0.56$ & $18.65 \pm 1.12$ & $21.11 \pm 0.74$ & 0.227 \\
\hline Frequency of anti-CCP positivity & $8(57.14 \%)$ & $29(70.73 \%)$ & 0 & - \\
\hline Frequency of RF positivity & $5(35.71 \%)$ & $19(46.34 \%)$ & $\mathbf{0}$ & - \\
\hline ESR & $22.69 \pm 5.18 \mathrm{~mm} / \mathrm{h}$ & $26.61 \pm 2.34 \mathrm{~mm} / \mathrm{h}$ & ND & - \\
\hline DAS-28 score & $3.91 \pm 0.45$ & $3.28 \pm 0.27$ & ND & - \\
\hline
\end{tabular}

RA: Rheumatoid arthritis, BMI: Body mass index, CCP: Cyclic citrullinated peptide, RF: Rheumatoid factor, ESR: Erythrocyte sedimentation rate, DAS-28: Disease activity score using 28 joint counts, ND: Not determined. Data are presented as mean \pm standard error.

Figure 1- Frequency of $T$ cells and subpopulations in RA patients and healthy controls. The Kruskal-Wallis with Dunn-Bonferroni post hoc test was used to compare the means of samples. Horizontal lines show median frequencies. Mean percentage of $\mathrm{CDB}^{+} \mathrm{T}$ cells (A) and $\mathrm{CD3}^{+} \mathrm{CD8}^{-\mathrm{T}}$ cells $(\mathrm{B})$ differed significantly between VERA and established RA patients $(* * \mathrm{P}<0.01)$.
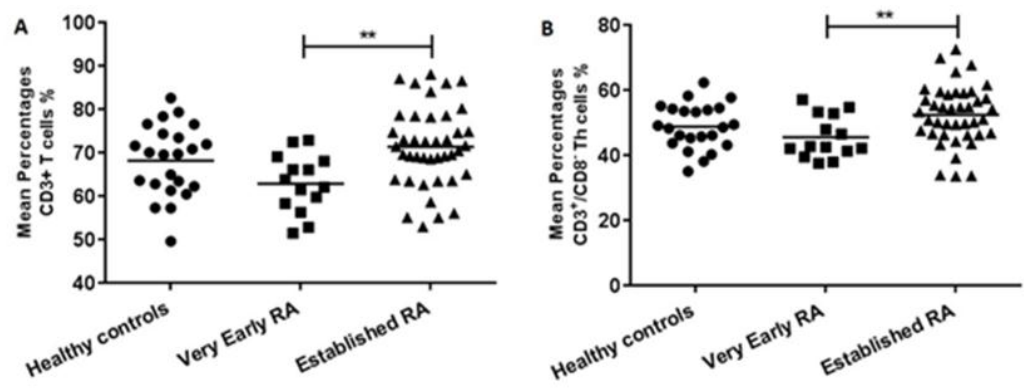
Frequency of Thelper 9 cells but not Th2 cells was increased significantly in $R A$ patients

As shown in Figure 2, there was no significant difference in the frequency of circulating Th2 cells between VERA patients $(1.71 \pm 0.43 \%)$, established RA patients $(1.52 \pm 0.45 \%)$ and healthy controls $(1.41 \pm 0.40 \%)$. Moreover, the mean percentage of circulating Th2 cells did not differ significantly between RA patients with and without active disease (Table 2).

As illustrated in Figure 2B, the mean percentage of circulating Th9 cells in VERA and established RA patients was significantly higher than that in the control group $(\mathrm{P}=0.009)$. In addition, the mean percentage of Th9 in established RA patients was not significantly different from that in VERA patients $(\mathrm{P}>0.05)$. There was no statistically significant difference in the mean percentage of circulating Th9 cells between RA patients with DAS-28 of $>3.2(1.47 \pm 0.58 \%)$ and those with DAS-28 of $<3.2(1.59 \pm 0.65 \%)(\mathrm{P}>0.05)$. As shown in table 2, mean percentage of circulating Th9 cells in VERA patients with inactive disease was significantly higher than that in those with active disease $(\mathrm{P}=0.01)$. There was a negative correlation between the DAS-28 score and the frequency of Th9 subset $(\mathrm{r}=-0.568, \mathrm{P}<0.05)$. In addition, there was a positive correlation between the frequency of CD8 ${ }^{-T}$ cells and the Th9 subset $(r=0.295$, $\mathrm{P}=0.008)$.

The mean percentage of circulating Th2 and Th9 cells did not differ significantly between ACPA-positive and ACPA-negative RA patients (Table 3). Same finding was obtained when comparing VERA and established RA patients. Mean serum level of IL-6 in both VERA and established RA patients was significantly higher than in healthy controls $(\mathrm{P}<0.01)$. However, there was no significant correlation between level of IL-6 and percentage of Th2 or Th9 cells $(\mathrm{P}>0.05)$.

Figure 2- Flow cytometry analysis of IL-4 and IL-9 expression on gated $\mathrm{CDB}^{+} \mathrm{CD8}^{-} \mathrm{T}$ cells. The Kruskal-Wallis with Dunn-Bonferroni post hoc test was used to compare the means of samples. Horizontal lines show median frequencies of the data. (A) Frequency of Th2 cells in RA patients and healthy controls. (B) Frequency of Th9 cells in RA patients and healthy controls $(* * \mathbf{P}<0.01)$.

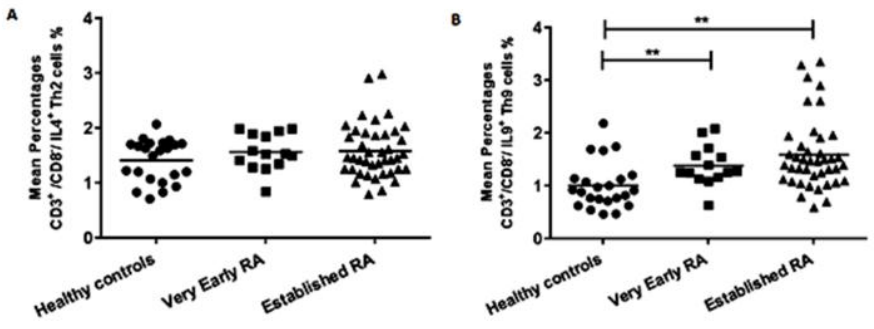

Table 2- Mean percentage of circulating Th2 and Th9 cells based on disease activity (DAS-28 score) in VERA and established RA patients.

\begin{tabular}{|c|c|c|c|}
\hline Variable & DAS-28 > 3.2 & DAS-28 $<3.2$ & P-value \\
\hline $\mathrm{CD3}^{+} \mathrm{CD8}^{-} \mathrm{IL}^{-4^{+}} \mathrm{T}$ cell in Established RA & $1.60 \pm 0.48$ & $1.49 \pm 0.44$ & 0.32 \\
\hline $\mathrm{CD3}^{+} \mathrm{CD8}^{-} \mathrm{IL}^{-4^{+}} \mathrm{T}$ cell in VERA & $1.59 \pm 0.26$ & $1.93 \pm 0.62$ & 0.26 \\
\hline $\mathrm{CD3}^{+} \mathrm{CD8}^{-}$IL-9 $^{+} \mathrm{T}$ cell in Established RA & $1.53 \pm 0.69$ & $1.60 \pm 0.66$ & 0.46 \\
\hline $\mathrm{CD3}^{+} \mathrm{CD8}^{-} \mathrm{IL}^{-9^{+}} \mathrm{T}$ cell in VERA & $1.17 \pm 0.25$ & $\mathbf{1 . 7 7} \pm \mathbf{0 . 5 7}$ & 0.01 \\
\hline
\end{tabular}

DAS-28: Disease activity score using 28 joint counts, $\mathrm{CD3}^{+} \mathrm{CD8}^{-} \mathrm{IL}_{-4}^{+}$: Th2 cells, $\mathrm{CD3}^{+} \mathrm{CD8}^{-} \mathrm{IL}^{-9^{+}}$:Th9 cells. Data are presented as mean \pm standard deviation.

Table 3- Mean percentage of circulating Th2 and Th9 cells among ACPA-positive and -negative RA patients.

\begin{tabular}{|c|c|c|c|}
\hline Variable & Anti-CCP (+) & Anti-CCP (-) & P-value \\
\hline $\mathrm{CD3}^{+} \mathrm{CD8}^{-} \mathrm{IL}^{-4^{+}} \mathrm{T}$ cell in Established $\mathrm{RA}$ & $1.56 \pm 0.44$ & $1.44 \pm 0.48$ & 0.87 \\
\hline $\mathrm{CD3}^{+} \mathrm{CD8}^{-} \mathrm{IL}_{-} 4^{+} \mathrm{T}$ cell in VERA & $1.79 \pm 0.53$ & $1.60 \pm 0.26$ & 0.41 \\
\hline $\mathrm{CD3}^{+} \mathrm{CD8}^{-} \mathrm{IL}^{-9^{+}}$in $\mathrm{T}$ cell Established $\mathrm{RA}$ & $1.66 \pm 0.72$ & $1.51 \pm 0.31$ & 0.37 \\
\hline $\mathrm{CD3}^{+} \mathrm{CD8}^{-} \mathrm{IL}^{-}{ }^{+} \mathrm{T}$ cell in VERA & $1.35 \pm 0.57$ & $1.77 \pm 0.57$ & 0.13 \\
\hline
\end{tabular}

CCP: Cyclic citrullinated peptide, $\mathrm{CD3}^{+} \mathrm{CD8}^{-} \mathrm{IL}_{-} 4^{+}$: Th2 cells, $\mathrm{CD3}^{+} \mathrm{CD8}^{-} \mathrm{IL}^{+}{ }^{+}$:Th9 cells. Data are presented as means \pm standard deviation. 


\section{DISCUSSION}

Th2 and Th9 cells are subsets with similar properties in immunity against parasitic infections and induction of allergic diseases (20). More careful analyses showed that Th9 cells are distinct from Th2 cells and can be differentiated from low numbers of activated $\mathrm{CD}^{+} \mathrm{T}$ cells in the presence of transforming growth factor $\beta$ and IL-4 or thymic stromal lymphopoietin $(21,22)$. Depending on the combined cytokine milieu in which Th9 lymphocytes are generated, these cells can be differentiated by several nonspecific transcription factors (23). Nevertheless, few studies have evaluated the role of these cells in patients with different stages of RA (24). In numerous experimental autoimmune disease models, Th9 cells have been found as primary contributors to the inflammatory progression (25). Previously, it had been indicated that Th9 cells are increased in RA patients compared to healthy controls $(11,26,27)$. Our results confirmed the findings of earlier studies regarding the significant increase in the frequency of circulating Th9 cells in RA patients. Furthermore, these findings indicated that the percentage of Th9 cells in the inactive group of VERA patients was significantly higher than that in the active group. Thus, Th9 cells seem to have a role in the disease initiation before the activation phase. These findings may be useful for achieving a successful disease remission by initiating an effective treatment in the first six months of RA onset (28). Established RA patients receiving therapy had more Th9 cells (1.62\%) than those who were not taking any medication (1.37\%), but this difference was not statistically significant $(\mathrm{P}=0.074)$. According to recent studies, Th9 cells are involved in the organization of lymphoid centers in synovial tissue and are important in the induction of joints deformities in RA patients (29). It has been proposed that Th9 cells may be also involved in RA pathogenesis by helping B cells produce RA-related autoantibodies, such as ACPAs $(24,30)$. However, we found no significant difference in the mean frequency of circulating Th9 cells between ACPA-positive and -negative RA patients. Ruocco et al. indicated that activation of Th9 cells mediated by plasmacytoid dendritic cells could have an immunoregulatory role in the Th17 cellsgenerated inflammation in multiple sclerosis (31). Nonetheless, the exact role of Th9 might rely on the tissue microenvironment and cytokines present in the milieu (32). Interleukin 6 is a critical cytokine in autoimmune diseases, including RA (33). The results of our study showed that the serum level of this pro-inflammatory cytokine was significantly higher in RA patients than in healthy controls. However, we failed to find a significant correlation between IL-6 and frequency of Th9 lymphocytes. Previous studies revealed that IL-6 does not influence IL-9 expression in naive $\mathrm{CD}^{+} \mathrm{T}$ cells (34). Thus, Th9 cells and IL-6 seem to be involved in separate inflammatory pathways in patients with RA. It has been suggested that Th2 may be associated with early steps of RA pathogenesis (6), but in line with a study by Chen et al. (35), we found no significant difference in the frequency of circulating Th2 cells between RA patients and healthy controls. Moreover, we found no significant difference in the mean frequency of circulating Th2 cells between ACPA-positive and negative RA patients. Previous studies have shown that both Th2 and Th9 cells are involved in human atopic diseases, but our data indicated that while Th9 frequency is increased significantly, frequency of $\mathrm{Th} 2$ lymphocyte is not altered significantly in RA patients. We also found that the prevalence of $\mathrm{CD}^{+} \mathrm{T}$ and $\mathrm{CD}^{-} \mathrm{CD}^{+} \mathrm{T}$ cells in the RA group was significantly higher than in the VERA group. Earlier studies have shown that the frequency of $\mathrm{T}$ and $\mathrm{Th}$ lymphocytes increases in patients with RA (36). Although in our study, the frequency of these cells in the established RA group was more than that in the control group, the difference was not statistically significant.

\section{CONCLUSION}

Our findings suggest that targeting Th9 cells could be a promising strategy for advanced RA therapies. However, further studies are required to increase our understandings of the exact role of Th9 cells in the pathogenesis of autoimmune diseases. 


\section{ACKNOWLEDGEMENTS}

This study received financial support from the Golestan University of Medical Sciences, Iran (Grant number: 931128255). We would like to thank Dr. Alireza Vafaeepour for his

\section{REFERENCES}

1. Scott DL, Wolfe F, Huizinga TW. Rheumatoid arthritis. Lancet. 2010; 376(9746): 1094-108. doi: 10.1016/S0140-6736(10)60826-4.

2. Uhlig T, Moe RH, Kvien TK. The burden of disease in rheumatoid arthritis. Pharmacoeconomics. 2014; 32(9): 841-851. doi: 10.1007/s40273-014-0174-6.

3. Cope AP, Schulze-Koops H, Aringer M. The central role of $T$ cells in rheumatoid arthritis. Clin Exp Rheumatol. 2007; 25(5 Suppl 46): S4-11.

4. Gizinski AM, Fox DA. T cell subsets and their role in the pathogenesis of rheumatic disease. Curr Opin Rheumatol. 2014; 26(2): 204-10. doi: 10.1097/BOR.0000000000000036.

5. Li P, Spolski R, Liao W, Leonard WJ. Complex interactions of transcription factors in mediating cytokine biology in T cells. Immunol Rev. 2014; 261(1): 141-156.

6. Burkett PR, Lee Y, Peters A, Kuchroo VK. T Cells and their Subsets in Autoimmunity. In: Rose NR, Mackay $I R$, editors. The Autoimmune Diseases. USA: Academic Press. 2014; 69-86.

7. Patel DD, Kuchroo VK. Th17 Cell Pathway in Human Immunity: Lessons from Genetics and Therapeutic Interventions. Immunity. 2015; 43 (6): 1040-1051. doi: 10.1016/j.immuni.2015.12.003.

8. van Vollenhoven RF. Rheumatoid arthritis in 2012: Progress in RA genetics, pathology and therapy. Nat Rev Rheumatol. 2013; 9(2): 70-2. doi: 10.1038/nrrheum.2012.232.

9. Pandya JM, Lundell AC, Hallström M, Andersson K, Nordström I, Rudin A. Circulating $T$ helper and $T$ regulatory subsets in untreated early rheumatoid arthritis and healthy control subjects. J Leukoc Biol. 2016; 100 (4): 823-833.

10. Kaplan MH, Hufford MM, Olson MR. The development and in vivo function of Thelper 9 cells. Nat Rev Immunol. 2015; 15(5): 295-307. doi: $10.1038 /$ nri3824

11. Végran F, Apetoh L, Ghiringhelli F. Th9 cells: $a$ novel CD4 T-cell subset in the immune war against cancer. Cancer Res. 2015; 75(3): 475-479.

12. Talotta R, Berzi A, Atzeni F, Dell'Acqua D, Sarzi Puttini P, Trabattoni D. Evaluation of Th9 lymphocytes in peripheral blood of rheumatoid arthritis patients and correlation with anti-tumor necrosis factor therapy: results from an in vitro pivotal study. Reumatismo. 2016; 68(2): 83-89.

13. Wilhelm C, Turner JE, Van Snick J, Stockinger B. The many lives of IL-9: a question of survival? Nat Immunol. 2012; 13(7): 637-641.

14. Veldhoen M, Uyttenhove C, van Snick J, Helmby H, Westendorf A, Buer J, et al. Transforming growth factorbeta 'reprograms' the differentiation of $T$ helper 2 cells and promotes an interleukin 9-producing subset. Nat Immunol. 2008; 9(12): 1341-1346. contribution to manuscript preparation.

\section{CONFLICT OF INTEREST}

We declare that there is no conflict of interest regarding publication of this article.

15. van der Helm-van Mil AH1, Verpoort KN, Breedveld FC, Toes RE, Huizinga TW. Antibodies to citrullinated proteins and differences in clinical progression of rheumatoid arthritis. Arthritis Res Ther. 2005; 7(5): R949-958.

16. Kourilovitch M, Galarza-Maldonado C, Ortiz-Prado E. Diagnosis and classification of rheumatoid arthritis. $\mathbf{J}$ Autoimmun. 2014; 48-49: 26-30. doi: 10.1016/j.jaut.2014.01.027.

17. Gremese E, Salaffi F, Bosello SL, Ciapetti A, Bobbio-Pallavicini F, Caporali R, et al. Very early rheumatoid arthritis as a predictor of remission: a multicentre real life prospective study. Ann Rheum Dis. 2013; 72(6): 858-62. doi: 10.1136/annrheumdis-2012201456.

18. van Riel PL, Renskers L. The Disease Activity Score (DAS) and the Disease Activity Score using 28 joint counts (DAS28) in the management of rheumatoid arthritis. Clin Exp Rheumatol. 2016; 34(5 Suppl 101): S40-S44.

19. Møller BK, Andresen BS, Christensen EI, Petersen CM. Surface membrane CD4 turnover in phorbol ester stimulated T-lymphocytes. Evidence of degradation and increased synthesis. FEBS Lett. 1990; 276 (1-2): 59-62. DOI:10.1016/0014-5793(90)80506-e.

20. Chang HC, Sehra S, Goswami R, Yao W, Yu Q, Stritesky GL, et al. The transcription factor PU.1 is required for the development of IL-9-producing $T$ cells and allergic inflammation. Nat Immunol. 2010; 11(6): 527-34. doi: 10.1038/ni.1867.

21. Ciccia F, Guggino G, Ferrante A, Cipriani P, Giacomelli R, Triolo G. Interleukin-9 and Thelper type 9 cells in rheumatic diseases. Clin Exp Immunol. 2016; 185(2):125-32. doi: 10.1111/cei.12807.

22. Yao W, Zhang Y, Jabeen R, Nguyen ET, Wilkes DS, Tepper RS, et al. Interleukin-9 is required for allergic airway inflammation mediated by the cytokine TSLP.

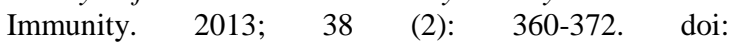
10.1016/j.immuni.2013.01.007.

23. Li J, Chen S, Xiao X, Zhao Y, Ding W, Li XC. IL-9 and Th9 cells in health and diseases-From tolerance to immunopathology. Cytokine Growth Factor Rev. 2017; 37: 47-55. doi: 10.116/j.cytogfr.2017.07.004.

24. Schmitt E, Klein M, Bopp T. Th9 cells, new players in adaptive immunity. Trends Immunol. 2014; 35(2): 618. doi: 10.1016/j.it.2013.10.004.

25. Jäger A, Dardalhon V, Sobel RA, Bettelli E, Kuchroo VK. Th1, Th17, and Th9 effector cells induce experimental autoimmune encephalomyelitis with different pathological phenotypes. J Immunol 2009; 183 (11): 7169-7177.

26. Chowdhury K, Kumar U, Das S, Chaudhuri J, Kumar P, Kanjilal M, et al. Synovial IL-9 facilitates neutrophil survival, function and differentiation of Th17 cells in rheumatoid arthritis. Arthritis Res Ther. 2018; 20(1): 18. doi: 10.1186/s13075-017-1505-8. 
27. Kundu-Raychaudhuri S, Abria C, Raychaudhuri SP. $I L-9$, a local growth factor for synovial $T$ cells in inflammatory arthritis. Cytokine. 2016; 79: 45-51. doi: 10.1016/j.cyto.2015.12.020.

28. Demoruelle MK, Deane KD. Treatment strategies in early rheumatoid arthritis and prevention of rheumatoid arthritis. Curr Rheumatol Rep. 2012; 14(5): 472-480.

29. Ciccia F, Guggino G, Rizzo A, Manzo A, Vitolo B, La Manna MP, et al. Potential involvement of IL-9 and Th9 cells in the pathogenesis of rheumatoid arthritis. Rheumatology (Oxford). 2015; 54(12): 2264-72. doi: 10.1093/rheumatology/kev252.

30. Hughes-Austin JM, Deane KD, Derber LA, Kolfenbach JR, Zerbe GO, Sokolove J, et al. Multiple cytokines and chemokines are associated with rheumatoid arthritis-related autoimmunity in first-degree relatives without rheumatoid arthritis: Studies of the Aetiology of Rheumatoid Arthritis (SERA). Ann Rheum Dis. 2013; 72 (6): 901-907.

31. Ruocco G, Rossi S, Motta C, Macchiarulo G, Barbieri F, De Bardi M, et al. Thelper 9 cells induced by plasmacytoid dendritic cells regulate interleukin-17 in multiple sclerosis. Clin Sci (Lond). 2015; 129(4): 291303.
32. Pan HF, Leng RX, Li XP, Zheng SG, Ye DQ. Targeting T-helper 9 cells and interleukin-9 in autoimmune diseases. Cytokine Growth Factor Rev. 2013; 24 (6): 515-522.

33. Hunter CA, Jones SA. IL-6 as a keystone cytokine in health and disease. Nat Immunol. 2015; 16(5): 448-457. 34. Beriou G1, Bradshaw EM, Lozano E, Costantino $\mathrm{CM}$, Hastings WD, Orban T, et al. TGF-beta induces $I L$ 9 production from human Th17 cells. J Immunol. 2010; 185(1): 46-54.

35. Chen J, Li J, Gao H, Wang C, Luo J, Lv Z. Comprehensive evaluation of different T-helper cell subsets differentiation and function in rheumatoid arthritis. J Biomed Biotechnol. 2012; 2012: e535361.

36. Koetz K, Bryl E, Spickschen K, O'Fallon WM, Goronzy JJ, Weyand CM. T cell homeostasis in patients with rheumatoid arthritis. Proc Natl Acad Sci USA. 2000; 97(16): 9203-9208. 